INTERNATIONAL JOURNAL OF RESEARCHES IN BIOSCIENCES, AGRICULTURE AND TECHNOLOGY (c) VISHWASHANTI MULTIPURPOSE SOCIETY (Global Peace Multipurpose Society) R. No. MH-659/13(N) www.ijrbat.in

\title{
INVESTIGATING ANTI STAPHYLOCOCCAL POTENTIAL OF NANOEMULSIONS OF CINNAMON AND CLOVE OILS FOR MRSA
}

\author{
Archana Kulkarni \\ Department of Microbiology, Dharampeth M.P.DEO Memorial Science College, \\ Nagpur, India \\ E-mail- archanakulkarni6212@gmail.com
}

\begin{abstract}
:
Methicillin resistant Staphylococcus aureus (MRSA) infections are posing threat to the community. They have high rate of mortality and requires longer hospital stays than do other S.aureus infections. To overcome this problem the use of volatile oils presents a more directly antimicrobial approach to MRSA infections. The essential oils of cinnamon and clove have antibacterial, antifungal, and anti-inflammatory properties. Here in this article anti Staphylococcal effect of cinnamon and clove oils nanoemulsions to combat MRSA were studied by using Tween 20(T20) and Tween 80 (T80) separately in the ratio of 1:1(oil to surfactant ratio), 1:2, 1:3,1:4. As reported earlier, since the droplet size of nanoemulsions of oils has direct role in deciding antibacterial activity, the droplet size and polydispersity index(pdi) studies were undertaken. Eight nanoemulsions were tested using agar well diffusion method out of which maximum antibacterial activity was exhibited by Cinnamon oil nanoemulsions formulation i.e. $80 \mathrm{C}_{4}$ (1:4 oil to T80 ratio) with mean value of ZOI as $35.07 \mathrm{~mm}$, followed by $20 \mathrm{C}_{4}$ (1:4 oil to T20 ratio) of $33.68 \mathrm{~mm}$, having droplet size of $133.6 \mathrm{~nm}$ and $272.3 \mathrm{~nm}$ respectively. Clove oil was found to show less activity with the maximum mean ZOI value as $16.23 \mathrm{~mm}$ for $20 \mathrm{Cl}_{2}$ (1:2 oil to T20ratio), and $14.27 \mathrm{~mm}$ for $80 \mathrm{Cl}_{1}(1: 1$ oil to T80 ratio). Our findings suggested that cinnamon oil nanoemulsions has a potential to be a herbal antibacterial agent.
\end{abstract}

Keywords: - MRSA, nanoemulsion, cinnamon oil, clove oil, Tween 20, Tween 80.

\section{INTRODUCTION:}

Antibiotic resistance is a major health concern globally and the resurgence of public interest towards natural therapies has renewed the interest in using essential oils as antimicrobial agents. Mostly essential oils from plants are widely used in agriculture, pharmaceutical, sanitary, cosmetics, and food industries because of their potent antimicrobial bioactive components, but still they pose some disadvantages- like poor solubility in aqueous medium, low stability, strong aroma and taste, strong organoleptic properties, low stability, volatile nature and limited availability of routes of administration (Huang et al., 2010). This limitation can overcome by mixing essential oil with surfactant and formulating nanoemulsions (Quian et al., 2012). Antimicrobial nanoemulsions are $\mathrm{O} / \mathrm{W}$ nanoemulsions with droplet size in range from 200-600 $\mathrm{nm}$ and are stabilized by surfactants and demonstrate broad spectrum activity against variety of microbes including their spores and viruses. The charge interaction between small oil droplets in nanoemulsion and microbial membrane is the reason for the interaction with microbes (www.nanobio.com). Nanoemulsions damage microbes by fusing with lipid bilayers of cell membrane, by releasing energy stored in oiland- emulsion destabilizing the lipid membrane of the bacteria (Hamouda et al., 2000). The nonspecific action of nanoemulsions, unlike that of antibiotics, thus renders its broad-spectrum effectivity while limiting the generation of resistance. These characteristics make nanoemulsion an appropriate option for both wound treatment (Hemmila et al., 2010) and surface decontamination (Ioannou et al.,2007). The drawbacks of bulk dosing of EO's thus can be mitigated by formulating them as nanoemulsions. These emulsions have an added advantage as they are in nanometer size range whose thermodynamic properties enable them to be used as an effective drug delivery system.

Essential oils contain variety of phytochemicals such as carvacrol, eugenol, thymol, cinnamaldehyde, terpineol etc. (Bilia 
et al., 2014). Significant antiseptic, antibacterial, antiviral, antioxidant, antiparasitic, antifungal and insecticidal activities have been demonstrated by essential oils (Kaloustian et al,. 2008; Benjilali et al.,1986; Burt 2004). Therefore, essential oil is considered as powerful antimicrobial agent to combat infections (Stefanakis., 2013).

So the main objective of this study was to investigate the Cinnamon and clove oils nano emulsions anti Staphylococcal effect on MRSA.

\section{MATERIALS AND METHODS:}

In the present study Cinnamon and Clove oils, surfactants-Tween 20 and Tween 80(SD fine chemicals), deionized water were procured commercially. Hi-sensitivity Test Agar, Nutrient Agar, and Nutrient Broth, from Hi-media Laboratories were used. Clinical isolates of methicillin resistant S.aureus were procured from Local Pathology laboratory from Nagpur.

\section{Nanoemulsion Formulations:}

In this work nanoemulsions of cinnamon and clove oils in water were formulated using nonionic surfactant such as Tween 20 and Tween 80 separately. Initially coarse emulsions were prepared with drop wise addition of deionized water to mixture comprising Essential Oil(EO) and Surfactant in ratio of $1: 1,1: 2,1: 3$, and $1: 4$ respectively with simultaneous stirring on magnetic stirrer at 400- $600 \mathrm{rpm}$ for approx.70 minutes (Table-I).

\section{Physicochemical Characterization Nanoemulsion Formulations:}

For testing physicochemical characteristics of nanoemulsions of cinnamon and clove oils, the $\mathrm{pH}$ studies, visual appearance and \% transmittance were carried out. The $\mathrm{pH}$ of all sixteen formulated essential oil nanoemulsions was tested using $\mathrm{pH}$ meter (Systronics-361), Visual appearance and \%Transmittance was checked with UVVisible spectrophotometer (Equiptronics) at
$600 \mathrm{~nm}$. All the parameters were analyzed in triplicates.

\section{Stability of Nanoemulsions}

Stability studies of prepared nanoemulsions were tested using Heating cooling cycle and thermodynamic stability studies.

\section{Heating -Cooling Cycle}

In this test the stability of all the 16 nanoemulsion formulations were checked at $40^{\circ} \mathrm{C}$ and $4^{\circ} \mathrm{C}$ respectively. Each of these nanoemulsions was kept at these temperatures alternatively for $48 \mathrm{hrs}$.

\section{Thermodynamic Stability}

To prove thermodynamic stability all the sixteen formulated nanoemulsions were centrifuged at $10,000 \mathrm{rpm}$ for 30 minutes and observed for phase separation if any.

\section{Antibacterial Activity of Cinnamon and Clove Oils Nanoemulsions by Agar Well diffusion method:}

To test the anti-Staphylococcal activity of all the nanoemulsions of cinnamon and clove oils, $100 \mu \mathrm{l}$ of $24 \mathrm{hrs}$.old nutrient broth culture of clinical isolates of MRSA, were inoculated on the respective sterilized $\mathrm{Hi}$ sensitivity Test Agar Plates. Broth culture was spread uniformly with sterile spreader. The wells were made using sterile borer.To each of the well $100 \mu$ of respective essential oil nanoemulsions was added using micropipette aseptically. All the plates were then kept in refrigerator for 30 minute so as to facilitate diffusion of nanoemulsion in f media along with bacteriostatic action of low temperature in refrigerator. All the plates were then incubated at $37{ }^{\circ} \mathrm{C}$ for $24 \mathrm{hrs}$.in bacteriological incubator. The zones of inhibition (ZOI) of bacterial growth were measured using zone size measurement scale. (Hi-media), and average value of three replicates were calculated for each isolate and recorded. The results obtained were compared using ANOVA test, student's t-test, post hoc tukeys test. 


\section{Measurement of Droplet Size of Nanoemulsions}

The Cinnamon and clove oils nanoemulsion formulations showing maximum zone of inhibition were selected for measurement of droplet size and polydispersity index (pdi). It was determined using 90 plus particle size analyzer (ZS, 90 Malvern Instruments, UK). Out of the 16 nanoemulsions tested $20 \mathrm{Cl}_{2}$ nanoemulsion of clove oil and $20 \mathrm{C}_{4}$ and 80 $\mathrm{C}_{4}$ nanoemulsion of cinnamon oil showing maximum ZOI were selected for droplet size measurement. Before analysis these nanoemulsions were diluted with deionizrd water to lower viscosity and multiple light scattering effects.

\section{RESULTS AND DISCUSSION}

\section{Physicochemical Characterization}

Nanoemulsions with higher surfactant concentration demonstrated higher \% transmittance (Table-II). In case of clove oil nanoemulsion formulations with surface concentration 1:4 $\left(20 \mathrm{Cl}_{4} \& 80 \mathrm{Cl}_{4}\right)$ showed higher \% transmittance as compared to cinnamon oil nanoemulsions. This rise in \% Transmission may be due to reduction in droplet diameter with increase in surfactant concentration (Chang et al., 2013., Saberi et al.,2013). Further Surfactant concentration found to affect the visual appearance of clove oil nanoemulsions more as compared to cinnamon oil nanoemulsions. (Table II) The $\mathrm{pH}$ in all 16 nanoemulsions was in the range of 6.0 to 6.5 .

\section{Stability of Nanoemulsions}

The increase in surfactant concentration considerably affected the stability of essential oil nanoemulsions. The stability of test oils nanoemulsions under study was increased by energy input during ultrasonication. In the Clove oil nanoemulsions $20 \mathrm{Cl}_{2} \& 80 \mathrm{Cl}_{4}$ were found to be thermodynamically stable (Table II). Out of 8 nanoemulsions of cinnamon oil, $20 \mathrm{C}_{4}$ and $80 \mathrm{C}_{4}$ demonstrated thermodynamic stability.

\section{Antibacterial Activity of Nanoemulsion by Agar-Well Diffusion Method:}

All sixteen formulated essential oil nanoemulsions were screened for its anti
Staphylococcal activity against clinical isolates of MRSA. ZOI in mm when compared for both the oils using statistical tests like One-way analysis of variance (ANOVA), Posthoc tukeys test and Students t-test showed the following results.

\section{Antibacterial activity of Clove (Syzygium aromaticum) oil Nanoemulsions on MRSA}

Out of the four nanoemulsions prepared with Tween 20 in clove oil $20 \mathrm{Cl}_{1}$ to $20 \mathrm{Cl}_{4}$, the mean change in ZOI was statistically significantly different with a p-value $<0.0001$ (Table III). Further, a post-hoc analysis using Tukey's test revealed that the mean measurement for $20 \mathrm{Cl}_{2}(16.23 \pm 1.24 \mathrm{~mm})$ was statistically significantly higher than the remaining concentrations with $\mathrm{p}$-values less than $<0.0001$.

When the antibacterial activity of all eight nanoemulsions of clove oil was compared in terms of mean of $\mathrm{ZOI}(\mathrm{mm})$ revealed that the mean measurement of nanoemulsion $20 \mathrm{Cl}_{1}$ $(14.17 \pm 1.61 \mathrm{~mm})$ was statistically significantly smaller compared to the means of $20 \mathrm{Cl}_{2}, 20 \mathrm{Cl}_{3}$ and $20 \mathrm{Cl}_{4}$ with p-values less than 0.05. Also, there was a statistically significant difference between $20 \mathrm{Cl}_{2}$ with nanoemulsions $20 \mathrm{Cl}_{3}, 20 \mathrm{Cl}_{4}, 80 \mathrm{Cl}_{1}, 80 \mathrm{Cl}_{2}$, $80 \mathrm{Cl}_{3}$, and $80 \mathrm{Cl}_{4}$ with p-values $<0.0001$. The mean measurement of $20 \mathrm{Cl}_{3}(14.92 \pm 1.71$ $\mathrm{mm})$ was statistically significantly higher than nanoemulsions $80 \mathrm{Cl}_{2}(14.18 \pm 1.46 \mathrm{~mm})$ and $80 \mathrm{Cl}_{3}(13.85 \pm 1.06 \mathrm{~mm})$ with $\mathrm{p}$-values 0.0218 and $<0.0001$ respectively. Further, there was also a significant difference between $20 \mathrm{Cl}_{4}$ with nanoemulsions $80 \mathrm{Cl}_{1}$, $80 \mathrm{Cl}_{2}, 80 \mathrm{Cl}_{3}$ and $80 \mathrm{Cl}_{4}$ with p-values $<0.05$.

Taking into account results obtained from stability of Clove oil nanoemulsions. nanoemulsion formulated using Tween20, $2 \mathrm{OCl}_{2}$ is selected due to maximum antibacterial activity against clinical isolates of MRSA.

\section{Antibacterial activity of Cinnamon (Cinnamomum zeylanicum) oil Nanoemulsions On MRSA}


The Table IV shows the comparison of diameter measurements of the zone of inhibition (ZOI) for different concentrations of cinnamon oil nanoemulsions on MRSA, using a one-way analysis of variance. Out of four different concentrations of nanoemulsions formulated using Tween20, $20 \mathrm{C}_{1}$ to $20 \mathrm{C}_{4}$, the mean change in diameter measurement of the ZOI was statistically significantly different with a p-value < 0.0001 . Further, a post-hoc analysis using Tukey's test revealed that the mean measurement for $20 \mathrm{C}_{4}(33.68 \pm 1.16 \mathrm{~mm})$ was statistically significantly higher than the remaining concentrations with $\mathrm{p}$-values < 0.0001 .

Out of the four nanoemulsions of cinnamon oil formulated with Tween 80, when mean of ZOI $(\mathrm{mm})$ of these formulations were compared it was observed that for nanoemulsions $80 \mathrm{C}_{1}$ to $80 \mathrm{C}_{4}$, the mean diameter measurements were statistically significantly different for nanoemulsions with a $\mathrm{p}$-value $<0.0001$. The post-hoc analysis was performed using Tukey's test, which revealed that the mean measurement of nanoemulsion $80 \mathrm{C}_{4}(35.07 \pm 1.10 \mathrm{~mm})$ was statistically significantly higher than the remaining nanoemulsions of cinnamon oil with Tween 80 with $p$-values $<0.0001$. There was also a significant difference between the mean measurements of $80 \mathrm{C} 1$ (30.28 \pm 0.90 $\mathrm{mm})$ and $80 \mathrm{C}_{2}(29.69 \pm 1.18 \mathrm{~mm})$ with a pvalue of 0.0031 . Taking into account results obtained from stability of Cinnamon oil nanoemulsions. Nanoemulsions of cinnamon oil with Tween 20 , i.e. $20 \mathrm{C}_{4}$ and with Tween 80 i.e. $80 \mathrm{C}_{4}$ were considered to have good antistaphylococcal activity for MRSA.

\section{Measurement of Droplet Size of Nanoemulsions:}

The droplet size and polydispersity index (pdi)(Table V) in case of $20 \mathrm{Cl}_{2}, 20 \mathrm{C}_{4}$ and $80 \mathrm{C}_{4}$ nanoemulsions when analyzed using photon correlation microscopy (Malvern Zetasizer) it was observed that lowest pdi of 0.382 was reported for Cinnamon oil nanoemulsion $\left(80 C_{4}\right)$ with droplet diameter of $133.6 \mathrm{~nm}$. This was followed by $20 \mathrm{C}_{4}$ with pdi of 0.573 and droplet diameter of $272.3 \mathrm{~nm}$, for $20 \mathrm{Cl}_{2}$ pdi of 0.622 and droplet diameter of 303.3 $\mathrm{nm}$. Therefore, $80 \mathrm{C}_{4}$ and $20 \mathrm{C}_{4}$ have a tendency to mono disperse in nature. This characteristic of cinnamon oil nanoemulsions can be directly correlated with highest antibacterial activity of this formulation.

Out of the sixteen nanoemulsions tested using Clove \& Cinnamon oils maximum anti Staphylococcal activity (in terms of mean of ZOI (mm)), against MRSA were demonstrated by stable clove oil nanoemulsion $20 \mathrm{Cl}_{2}$ and $20 \mathrm{C}_{4}$ and, $80 \mathrm{C}_{4}$ nanoemulsions of cinnamon oil respectively. Comparison of mean of diameter of zone of inhibition obtained in these nanoemulsion formulations demonstrated maximum antibacterial activity in Cinnamon nanoemulsion formulation $80 \mathrm{C}_{4}$ with mean value of zone of inhibition of $35.07 \mathrm{~mm}$, followed by $20 \mathrm{C}_{4}$ of $33.68 \mathrm{~mm}$, against clinical isolates of MRSA. The considerable antistaphylococcal activity of Cinnamon oil nanoemulsion may be due to the potent antibacterial constituents of cinnamon oil, as well as reduced droplet diameter of cinnamon oil nanoemulsions as compared to that of nanoemulsions of clove oil under study. The results obtained corroborates with findings of Ghosh et al. (2013) who reported that cinnamon oil nanoemulsions demonstrates potent antibacterial activity .The antibacterial activity results obtained also corroborates with the findings of Donsi et al.,2012, who reported that ,cinnamaldehyde nanoemulsion greatly inhibits bacterial pathogens.

\section{CONCLUSION:}

Cinnamon oil based Stable nanoemulsions$20 \mathrm{C}_{4} \quad \& \quad 80 \mathrm{C}_{4}$ containing Tween20 and Tween 80 in $1: 4$ concentration as surfactant with droplet diameter in $272.3 \mathrm{~nm}$ and 133.6 $\mathrm{nm}$ respectively demonstrated maximum bactericidal activity against clinical isolates of MRSA. Thus cinnamon oil can be exploited to prepare natural potent antibacterial nanoemulsion against MRSA.

\section{ACKNOWLEDGMENTS:}


We deeply acknowledge R.C.Patel college of Pharmacy, Shirpur, Maharashtra for providing consultancy in droplet size measurement \& pdi studies.

\section{REFERENCES}

Bilia Anna Rita, Francesca Santomauro, Cristiana Sacco, Maria Camilla Bergonzi, and Rosa Donato,(2014)."Essential Oil of Artemisia annua L.: An Extraordinary Component with Numerous Antimicrobial Properties," Evidence-Based Complementary and Alternative Medicine, vol. 2014, Article ID 159819 , 7 pages.

Benjilali, B., Tantaoui-Elaraki, A., IsmailiAlaoui, M., \& Ayadi, A. (1986). Méthode d'étude des propriétés antiseptiques des huiles essentielles par contact direct en milieu gélosé. Plantes médicinales et phytothérapie, 20(2), 155-167.

Burt, S. (2004). Essential oils: their antibacterial properties and potential applications in foods-a review. International journal of food microbiology, 94(3), 223-253.

Chang, Y., McLandsborough, L., \& McClements, D. J. (2013). Physicochemical properties and antimicrobial efficacy of carvacrol nanoemulsions formed by spontaneous emulsification. Journal of agricultural and food chemistry, 61(37), 89068913.

Donsì, F., Annunziata, M., Vincensi, M., \& Ferrari, G. (2012). Design of nanoemulsion-based delivery systems of natural antimicrobials: effect of the emulsifier. Journal of biotechnology, 159(4), 342-350.

Ghosh, V.; Sugumar, S.; Mukherjee, A.; Chandrasekaran, N.(2013) Cinnamon oil nanoemulsion formulation by ultrasonic emulsification: Investigation of Its bactericidal activity. J. Nanosci. Nanotechnol., 13, 114-122.

Hamouda, T., \& Baker Jr, J. R. (2000). Antimicrobial mechanism of action of surfactant lipid preparations in enteric Gram-negative bacilli. Journal of applied microbiology, 89(3), 397-403.

Hemmila, M. R., Mattar, A., Taddonio, M. A., Arbabi, S., Hamouda, T., Ward, P. A., ... \& Baker Jr, J. R. (2010). Topical nanoemulsion therapy reduces bacterial wound infection and inflammation after burn injury. Surgery, 148(3), 499-509.

Huang, Q., Yu, H., \& Ru, Q. (2010). Bioavailability and delivery of neutraceuticals using nanotechnology. Journal of food science, 75(1), R50-R57.

Ioannou, C. J., Hanlon, G. W., \& Denyer, S. P. (2007). Action of disinfectant quaternary ammonium compounds against Staphylococcus aureus. Antimicrobial agents and chemotherapy, 51(1), 296-306.

Kaloustian, J., Chevalier, J., Mikail, C., Martino, M., Abou, L., \& Vergnes, M. F. (2008). Study of six essential oils: chemical composition and antibacterial activity. Phytotherapie, 6(3), 160.

Qian, C., Decker, E. A., Xiao, H., \& McClements, D. J. (2012). Physical and chemical stability of $\beta$-caroteneenriched nanoemulsions: Influence of $\mathrm{pH}$, ionic strength, temperature, and emulsifier type. Food chemistry, 132(3), 1221-1229.

Saberi, A. H., Fang, Y., \& McClements, D. J. (2013). Effect of glycerol on formation, stability, and properties of vitamin-E enriched nanoemulsions produced using spontaneous emulsification. Journal of colloid and interface science, 411, 105-113. 
Stefanakis, M. K., Touloupakis, E., Anastasopoulos, E., Ghanotakis, D., Katerinopoulos, H. E., \& Makridis, P. (2013). Antibacterial activity of

\section{Table I: Composition of Cinnamon and Clove Oils Nanoemulsions}

\begin{tabular}{|c|c|c|c|c|c|c|}
\hline \multirow{2}{*}{ Essential Oil } & \multirow{2}{*}{$\begin{array}{c}\text { Nanoemulsion } \\
\text { code }\end{array}$} & \multirow{2}{*}{$\begin{array}{l}\text { Type of } \\
\text { Surfactant } \\
\text { Used }\end{array}$} & \multirow{2}{*}{$\begin{array}{l}\text { Oil: } \\
\text { surfactant } \\
\quad \text { ratio }\end{array}$} & \multicolumn{3}{|c|}{$\begin{array}{c}\% \text { Composition of Different } \\
\text { components in Formulations }(50 \mathrm{ml})\end{array}$} \\
\hline & & & & $\begin{array}{l}\text { EO } \\
(\mathbf{m l})\end{array}$ & $\begin{array}{c}\text { Surfactant } \\
\text { ml) }\end{array}$ & $\begin{array}{l}\text { Deionized } \\
\text { Water(ml) }\end{array}$ \\
\hline \multirow[t]{8}{*}{ Clove Oil } & $20 \mathrm{Cl}_{1}$ & Tween20 & $1: 1$ & 3 & 3 & 46 \\
\hline & $20 \mathrm{Cl}_{2}$ & & $1: 2$ & 3 & 6 & 41 \\
\hline & $20 \mathrm{Cl}_{3}$ & & $1: 3$ & 3 & 9 & 38 \\
\hline & $20 \mathrm{Cl}_{4}$ & & $1: 4$ & 3 & 12 & 35 \\
\hline & $80 \mathrm{Cl}_{1}$ & Tween80 & $1: 1$ & 3 & 3 & 46 \\
\hline & $80 \mathrm{Cl}_{2}$ & & $1: 2$ & 3 & 6 & 41 \\
\hline & $\mathrm{80Cl}_{3}$ & & $1: 3$ & 3 & 9 & 38 \\
\hline & $80 \mathrm{Cl}_{4}$ & & $1: 4$ & 3 & 12 & 35 \\
\hline \multirow{8}{*}{$\begin{array}{l}\text { Cinnamon } \\
\text { Oil }\end{array}$} & $20 \mathrm{C}_{1}$ & Tween20 & $1: 1$ & 3 & 3 & 46 \\
\hline & $20 \mathrm{C}_{2}$ & & $1: 2$ & 3 & 6 & 41 \\
\hline & $20 \mathrm{C}_{3}$ & & $1: 3$ & 3 & 9 & 38 \\
\hline & $20 \mathrm{C}_{4}$ & & $1: 4$ & 3 & 12 & 35 \\
\hline & $80 C_{1}$ & Tween80 & 1:1 & 3 & 3 & 46 \\
\hline & $80 C_{2}$ & & $1: 2$ & 3 & 6 & 41 \\
\hline & $80 C_{3}$ & & $1: 3$ & 3 & 9 & 38 \\
\hline & $80 C_{4}$ & & $1: 4$ & 3 & 12 & 35 \\
\hline
\end{tabular}

Table II: Physicochemical Characterization \& Stability study of Cinnamon (C) \& Clove Oils (CI) Nanoemulsions

\begin{tabular}{|c|c|c|c|c|c|}
\hline \multicolumn{6}{|c|}{ Nanoemulsions } \\
\hline $\begin{array}{c}\text { Nano emulsion } \\
\text { Formulation Code }\end{array}$ & $\begin{array}{c}\text { Visual } \\
\text { Appearance }\end{array}$ & $\% \mathrm{~T}$ & pH & $\mathbf{C}$ & $\begin{array}{l}\text { H- } \\
\text { C }^{*}\end{array}$ \\
\hline $20 \mathrm{Cl}_{1}$ & Milky Yellow & 14 & 6.1 & - & - \\
\hline $20 \mathrm{Cl}_{2}$ & Milky Yellow & 15 & 6.0 & + & + \\
\hline $20 \mathrm{Cl}_{3}$ & Translucent & 18 & 6.0 & - & - \\
\hline $20 \mathrm{Cl}_{4}$ & Transparent & 85 & 6.0 & - & + \\
\hline $80 \mathrm{Cl}_{1}$ & Milky Yellow & 12 & 6.2 & - & - \\
\hline $80 \mathrm{Cl}_{2}$ & Milky Yellow & 14 & 6.1 & - & - \\
\hline $80 \mathrm{Cl}_{3}$ & Milky Yellow & 13 & 6.0 & - & - \\
\hline $80 \mathrm{Cl}_{4}$ & Transparent & 85 & 6.0 & + & + \\
\hline $20 \mathrm{C}_{1}$ & Milky & 15 & 6.0 & - & - \\
\hline $20 \mathrm{C}_{2}$ & Yellowish White & 14 & 6.0 & - & - \\
\hline $20 \mathrm{C}_{3}$ & Yellowish Milky & 15 & 6.0 & + & - \\
\hline $20 \mathrm{C}_{4}$ & Off White & 14 & 6.0 & + & + \\
\hline $80 \mathrm{C}_{1}$ & Milky White & 15 & 6.0 & - & - \\
\hline $80 \mathrm{C}_{2}$ & Milky White & 17 & 6.0 & - & - \\
\hline $80 C_{3}$ & Milky White & 14 & 6.0 & - & - \\
\hline $80 \mathrm{C}_{4}$ & Yellowish White & 12 & 6.0 & + & + \\
\hline
\end{tabular}

$\% \mathrm{~T}=\%$ Transmittance, $\mathrm{C}$ - Centrifugation, $+=$ stable, - =unstable essential oils from plants of the genus Origanum. Food control, 34(2), 539546.
\% $\%$ Transmittance, $\mathrm{C}$ - Centifugation, t=stable, = 
Table III: Comparison of diameter measurements of ZOI of different concentrations of Clove oil(C1) nanoemulsions on MRSA

\begin{tabular}{|c|c|c|c|c|c|c|c|}
\hline \multirow{2}{*}{$\begin{array}{l}\text { Nanoemulsion } \\
\text { code }\end{array}$} & \multicolumn{5}{|c|}{ Diameter of Zone of Inhibition (ZOI)m in $\mathbf{~ m m}$} & \multirow{2}{*}{ P-value ${ }^{*}$} & \multirow{2}{*}{ P-value ${ }^{\dagger}$} \\
\hline & Reference & Mean & SD & Minimum & Maximum & & \\
\hline $20 \mathrm{Cl}_{1}$ & 16.00 & 14.17 & 1.61 & 12.00 & 17.00 & \multirow{4}{*}{$<0.0001$ (S) } & \multirow{8}{*}{$<0.0001$ (S) } \\
\hline $20 \mathrm{Cl}_{2}$ & 20.00 & 16.23 & 1.24 & 14.00 & 20.00 & & \\
\hline $20 \mathrm{Cl}_{3}$ & 17.00 & 14.92 & 1.71 & 12.00 & 17.00 & & \\
\hline $20 \mathrm{Cl}_{4}$ & 20.00 & 14.96 & 1.16 & 12.00 & 20.00 & & \\
\hline $80 \mathrm{Cl}_{1}$ & 16.00 & 14.27 & 0.97 & 12.00 & 16.00 & \multirow{4}{*}{0.0605 (NS) } & \\
\hline $80 \mathrm{Cl}_{2}$ & 19.00 & 14.18 & 1.46 & 12.00 & 19.00 & & \\
\hline $80 \mathrm{Cl}_{3}$ & 15.00 & 13.85 & 1.06 & 12.00 & 15.00 & & \\
\hline $80 \mathrm{Cl}_{4}$ & 13.00 & 13.86 & 1.11 & 12.00 & 15.00 & & \\
\hline
\end{tabular}

Antibacterial activity of Cinnamon (Cinnamomum zeylanicum) oil Nanoemulsions On MRSA

Table IV: Comparison of diameter measurements of ZOI of different concentrations of Cinnamon oil(C) nanoemulsions on MRSA

\begin{tabular}{|c|c|c|c|c|c|c|c|}
\hline \multirow{2}{*}{$\begin{array}{l}\text { Nanoemuls } \\
\text { ion code }\end{array}$} & \multicolumn{5}{|c|}{ Diameter of Zone of Inhibition (ZOI) $\mathrm{m}$ in $\mathrm{mm}$} & \multirow[b]{2}{*}{ P-value ${ }^{*}$} & \multirow[b]{2}{*}{ P-value ${ }^{\dagger}$} \\
\hline & $\begin{array}{c}\text { Refere } \\
\text { nce }\end{array}$ & Mean & SD & $\begin{array}{c}\text { Minimu } \\
\mathbf{m}\end{array}$ & Maximum & & \\
\hline $20 C_{1}$ & 31.00 & 29.99 & 0.78 & 29.00 & 31.00 & \multirow{4}{*}{$\begin{array}{c}<0.0001 \\
(\mathrm{~S})\end{array}$} & \multirow{8}{*}{$\begin{array}{c}<0.0001 \\
(\mathrm{~S})\end{array}$} \\
\hline $20 C_{2}$ & 30.00 & 29.75 & 1.37 & 20.00 & 31.00 & & \\
\hline $20 \mathrm{C}_{3}$ & 30.00 & 30.13 & 0.77 & 29.00 & 32.00 & & \\
\hline $20 C_{4}$ & 35.00 & 33.68 & 1.16 & 30.00 & 35.00 & & \\
\hline $80 \mathrm{C}_{1}$ & 34.00 & 30.28 & 0.90 & 29.00 & 34.00 & \multirow{4}{*}{$\begin{array}{c}<0.0001 \\
\text { (S) }\end{array}$} & \\
\hline $80 \mathrm{C}_{2}$ & 34.00 & 29.69 & 1.18 & 28.00 & 35.00 & & \\
\hline $80 C_{3}$ & 34.00 & 29.72 & 0.81 & 28.00 & 34.00 & & \\
\hline $80 C_{4}$ & 40.00 & 35.07 & 1.10 & 31.00 & 40.00 & & \\
\hline
\end{tabular}

Table V: Droplet size measurement of Cinnamon and Clove Oils Nano emulsions

\begin{tabular}{|c|c|c|}
\hline $\begin{array}{c}\text { Nano } \\
\text { emulsion } \\
\text { code }\end{array}$ & Pdi Index & $\begin{array}{l}\text { Droplet diameter } \\
\text { (nm) } \\
\text { z-average }\end{array}$ \\
\hline $0^{2} l_{2}$ & 0.622 & 303.3 \\
\hline $20 C_{4}$ & 0.573 & 272.3 \\
\hline $80 C_{4}$ & 0.382 & 133.6 \\
\hline
\end{tabular}

